\title{
SETTING RUANG TERBUKA DI KAWASAN WATERFRONT CITY PONTIANAK TANGGAP PANDEMI COVID-19
}

\author{
Hastika Tri Aprilla $^{1}$, M. Nurhamsyah ${ }^{2}$, B. Jumaylinda Br. Gultom ${ }^{3}$ \\ ${ }^{1}$ Mahasiswa, Jurusan Arsitektur, Fakultas Teknik, Universitas Tanjungpura. \\ hastikatriaprilla@gmail.com \\ ${ }^{2}$ Jurusan Arsitektur, Fakultas Teknik, Universitas Tanjungpura \\ ${ }^{3}$ Jurusan Arsitektur, Fakultas Teknik, Universitas Tanjungpura
}

Naskah diajukan pada: 18 Juni 2021

Naskah revisi akhir diterima pada: 24 Juni 2021

\begin{abstract}
Abstrak
Penelitian ini didasari dari pentingnya ruang terbuka bagi sebuah kota maupun masyarakat di dalamnya serta pandemi covid-19 yang sedang mewabah. Pandemi covid-19 membentuk batasan-batasan untuk menghindari penyebarannya. Hal-hal yang perlu dihindari antara lain kontak fisik, berkumpul dalam jumlah ramai, dan sebagainya. Kota Pontianak memiliki sebuah ruang terbuka yang berada di tepian (sempadan) Sungai Kapuas yaitu Waterfront City Pontianak. Waterfront City Pontianak masih ramai dikunjungi meski pandemi covid-19 sedang terjadi. Ramainya pengunjung menjadi kekhawatiran karena dapat menjadi ladang persebaran pandemi covid-19. Berdasarkan isu dan fenomena yang terjadi dirasa perlu adanya setting ruang terbuka di kawasan Waterfront City Pontianak yang tanggap pandemi covid-19. Penelitian ini berkaitan dengan perilaku manusia dan ruang, sehingga metode yang digunakan adalah metode behavior mapping dengan jenis place centered mapping. Metode place centered mapping didukung dengan penyebaran kuesioner. Hal selanjutnya yang dilakukan adalah tinjauan protokol kesehatan covid-19, yang telah ditentukan oleh Kementerian Kesehatan (Kemenkes). Hasil dari penelitian menunjukkan setting ruang Waterfront City Pontianak belum tanggap pandemi covid-19. Hal-hal yang perlu diperbaiki atau ditambahkan antara lain, penambahan penanda penjaga jarak di lantai, perubahan desain fasilitas tempat duduk dan pot tanaman yang ada, penyediaan fasilitas pos kesehatan covid-19, serta penyediaan fasilitas cuci tangan, handsanitizer dan media informasi covid-19.
\end{abstract}

Kata-kata Kunci: Setting ruang, Waterfront City Pontianak, Pandemi, Covid-19

\begin{abstract}
This research is based on the importance of open space for a city and the people in it as well as the covid-19 pandemic that happened. The covid-19 pandemic has established boundaries to prevent its spread. Things to avoid include physical contact, gathering in large numbers, and so on. Pontianak City has an open space located on the edge border of the Kapuas River, namely Waterfront City Pontianak. Waterfront City Pontianak is still crowded even though the covid-19 pandemic is happening. The number of visitors is a concern because it can become a field for the spread of the covid-19 pandemic. Based on the issues and phenomena that occurred, it was deemed necessary to have an open space setting in the Pontianak Waterfront City area that was responsive to the covid-19 pandemic. This research is related to human behavior and space, so the method that used is behavior mapping method with the type of place centered mapping. The place centered mapping method is supported by distributing questionnaires. The next thing to do is review the covid-19 health protocol, which has been determined by the Ministry of Health (Kemenkes). The results of the study show that the Waterfront City Pontianak setting has not responded to the covid-19 pandemic. Things that need to be improved or added include adding distance markers on the floor, changing the design of existing seating facilities and plant pots, providing covid-19 health post facilities, as well as providing hand washing facilities, hand sanitizers and information media for covid-19.
\end{abstract}

Keywords: Space Setting, Waterfront City Pontianak, Pandemic, Covid-19 


\section{Pendahuluan}

Salah satu elemen kota yang kehadirannya diperlukan bagi kota itu sendiri dan masyarakat didalamnya adalah ruang terbuka. Ruang terbuka merupakan ruang-ruang dalam kota atau wilayah yang lebih luas bisa berbentuk area atau kawasan di mana dalam penggunaannya bisa difungsikan sebagai tempat-tempat pertemuan dan aktivitas bersama di udara terbuka (Samsudi, 2010 dan Santoso, 2012). Peraturan Menteri Dalam Negeri Nomor 1 tahun 2007 menyebutkan beberapa Jenis RTHKP (Ruang terbuka Hijau Kawasan Perkotaan) antara lain taman kota, sempadan sungai, kawasan jalur hijau dan lain sebagianya. Pontianak merupakan kota yang dilalui oleh Sungai Kapuas, sehingga terdapat ruang terbuka berupa jalur sepadan Sungai Kapuas atau yang lebih dikenal dengan Waterfront City Pontianak. Waterfront City Pontianak dapat dimanfaatkan penduduk untuk melakukan berbagai kegiatan sosial, jual-beli, bersantai serta aktivitas-aktivitas lain yang bersifat terbuka untuk umum sehingga dapat menyebabkan kontak fisik.

Saat ini dunia sedang menghadapi Pandemi Covid-19. Coronovirus (Covid-19) dimulai pada bulan desember 2019 dan baru disadari pada bulan januari 2020, berasal dari Wuhan, Hubei, China (Hua \& Shaw, 2020; Kraemer et al., 2020). Hal ini menyebabkan banyak negara menerapkan social distancing atau menjaga jarak, serta penerapan protokol kesehatan lainnya seperti karantina. Pandemi Covid-19 masuk ke Indonesia pada bulan maret yang kemudian menyebar hingga grafik positif yang terjangkit Covid-19 di Indonesia terus meningkat. Beberapa ruang terbuka ada yang ditutup dan tidak bisa diakses oleh masyarakat. Penutupan ruang terbuka ini dilakukan untuk menghindari gerombolan manusia yang dapat menyebabkan penyebaran Covid-19 yang lebih luas sehingga membentuk rantai virus yang semakin panjang.

Penerapan protokol kesehatan seperti karantina mengharuskan masyarakat untuk menetap dirumahnya masing-masing. Manusia yang pada dasarnya memiliki kebutuhan untuk rekreasi, bersantai ataupun melakukan hal bebas lainnya akan menjadi tertekan atau stress jika diharuskan menetap dirumah dan dibatasi untuk keluar rumah. Menurut Larasati (2016), stres dapat menyebabkan deregulasi sistem imun, atau penurunan sistem imun tubuh. Penurunan imunitas tubuh dapat menyebabkan manusia lebih mudah terserang sakit atau terjangkit virus. Hal ini tentu tidak diinginkan untuk terjadi, sehingga perlu adanya penghilang stress yang aman saat masa pandemi ini. Setelah penelitian bertahun-tahun, Dr. Mary Carol Hunter yang merupakan seorang arsitek lansekap, ahli ekologi menyatakan bahwa hanya dengan 20 menit berada di alam akan memiliki manfaat besar untuk manusia. Hal ini menjadi alasan pentingnya peran taman untuk manusia (Hunter et al., 2019).

Meski belum adanya penurunan signifikan dari grafik persebaran Covid-19, Indonesia mencoba untuk memulai kembali kehidupan normal yang baru atau disebut juga dengan new normal pada kota berzona hijau salah satunya adalah Kota Pontianak. New normal di Indonesia dimulai pada tanggal 1 Juni 2020 dengan fase-fase bertahap hingga yang diawali dengan legalnya masyarakat untuk keluar rumah dan berkunjung ke area-area umum atau ruang terbuka. Hal ini disambut dengan baik oleh masyarakat, terlihat dengan ramainya pengunjung Waterfront City Pontianak, baik itu yang datang perorangan maupun dalam jumlah banyak. Fenomena ini mulai menjadi kekhawatiran karena terbentuknya gerombolan manusia disaat pandemi belum sepenuhnya berakhir.

Gerombolan manusia dapat meningkatkan grafik penyebaran Covid-19 sehingga dapat menyebabkan diberlakukan karantina kembali. Selain adanya gerombolan manusia, penggunaan fasilitas umum yang ada di Waterfront City Pontianak secara bersamaan tanpa adanya batasan tertentu dapat menjadi sarana penyebaran Covid-19 kembali. Melihat pentingnya ruang terbuka baik bagi masyarakat maupun bagi kota itu sendiri serta fenomena yang saat ini terjadi, dirasa perlu adanya sebuah pengaturan atau setting ruang terbuka yang aman untuk digunakan oleh masyarakat saat masa pandemi. Untuk itu dilakukan penelitian berjudul "Setting Ruang Terbuka di Kawasan Waterfront City Pontianak Tanggap Pandemi Covid-19" dengan tujuan mengetahui setting Waterfront City Pontianak yang aman dikunjungi saat pandemi covid-19 dengan menggunakan metode behavior mapping (pemetaan perilaku) yaitu place centered mapping serta kuesioner. 


\section{Kajian Pustaka \\ Ruang Terbuka Publik}

Ruang terbuka adalah istilah luas yang dapat digunakan untuk menggambarkan semua lahan yang tidak mengandung bangunan dan bangunan, ini dapat mencakup publik dan tanah pribadi (Nochian et al., 2015). Sunaryo (2010) mengatakan bahwa ruang terbuka mengakomodasi aktivitas publik. Berkaitan dengan hal tersebut, sebuah ruang terbuka umumnya juga dikenal dengan ruang terbuka publik. Ruang publik dapat berperan sebagai salah satu elemen kota yang dapat memberikan karakter tersendiri yang berkaitan dengan fungsi dari ruang publik itu sendiri (Darmawan, 2007). Purnomohadi dalam Shani \& Kurniawan (2015), mengatakan bentuk-bentuk RTH dapat diklasifikasikan sebagai taman kota (city park), jalur (tepian) sempadan sungai dan pantai, taman olahraga, relaksasi, taman pemakaman (umum), pertanian kota, taman (hutan) kota/perhutanan, taman situ, danau, waduk, empang, kebun raya, taman purbakala, jalur hijau pengaman, dan taman rumah.

\section{Setting (Penataan) dan Perilaku Pengguna}

Menurut Avenzoar et al., (2013), aspek penataan taman kota terdiri dari penataan internal dan eksternal. Aspek internal terdiri dari identitas dan tema, luas, fasilitas, material, sistem sirkulasi dan tata ruang. Aspek eksternal terdiri dari jaringan jalan, tata guna lahan, dan keterhubungan (linkage) kawasan. Menurut Yustiara \& Nirwansyah (2018); Nur'aini et al., (2018), setiap perencanaan dan perancangan tidak terlepas dari perilaku manusia sehingga arsitektur yang dibuat atas dasar kebutuhan manusia menghasilkan efek perilaku yang berbeda terhadap arsitektur itu sendiri. Berkaitan dengan hal tersebut, membuat sebuah perancangan atau penataan arsitektur perlu di hubungkan dengan konsep arsitektur lingkungan dan perilaku. Haryadi dan Setiawan (2014) menjelaskan beberapa konsep penting kajian arsitektural lingkungan dan perilaku, yaitu: [1] Seting Perilaku, [2] Persepsi tentang Lingkungan, [3] Lingkungan yang Tersepsikan, [4] Kognisi Lingkungan, Citra, dan Skemata, [5] Pemahaman Lingkungan, [6] Kualitas Lingkungan, [7] Teritori, [8] Ruang Personal dan Kesumpekan, dan [9] Tekanan Lingkungan, Stres, dan Strategi Penanggulangannya.

\section{Pandemi Covid-19}

Coronovirus (Covid-19) dimulai pada bulan desember 2019 dan baru disadari pada bulan januari 2020, berasal dari Wuhan, Hubei, China (Hua \& Shaw, 2020; Kraemer et al., 2020). Menurut Susilo et al., (2020), saat ini transmisi utama virus Covid-19 adalah dari manusia ke manusia, sehingga penyebarannya lebih agresif. Dalam tulisannya Fadli (2020) menjelaskan seseorang dapat tertular COVID-19 melalui berbagai cara, yaitu: [1] Tidak sengaja menghirup percikan ludah (droplet) yang keluar saat penderita COVID-19 batuk atau bersin, [2] Memegang mulut atau hidung tanpa mencuci tangan terlebih dulu setelah menyentuh benda yang terkena cipratan ludah penderita COVID-19, dan [3] Kontak jarak dekat dengan penderita COVID-19.

Menurut Telaumbanua (2020), untuk melakukan pencegahan terhadap penyebaran virus Covid-19, perlu adanya pembentukan Peraturan Pemerintah dan Peraturan Menteri Kesehatan. Berkaitan dengan hal tersebut, sudah adanya Keputusan Menteri Kesehatan Republik Indonesia Nomor Hk.01.07/Menkes/382/2020 Tentang Protokol Kesehatan Bagi Masyarakat di Tempat dan Fasilitas Umum Dalam Rangka Pencegahan dan Pengendalian Corona Virus Disease 2019 (Covid19). Peraturan yang berkaitan dengan ruang terbuka disaat pandemi covid-19 antara lain: [1] Peerapan jaga jarak, [2] Penyediaan fasilitas cuci tangan, [3] Penyediaan pos kesehatan, [4] Penyediaan media informasi. 


\section{Pemetaan Perilaku (Behaviour Mapping)}

Pemetaan perilaku (behaviour mapping) merupakan metode objektif untuk mengamati perilaku dan lingkungan binaan terkait komponen-kompenen dan atribut yang ada (Cosco et al., 2010). Sanoff \& Coates (1971) mengatakan tujuan dari pemetaan perilaku adalah untuk mempelajari fenomena perilaku yang terjadi dalam lingkungan alaminya. Ratodi (2017) mengatakan pemetaan perilaku (behaviour mapping) ini dapat digunakan saat merencanakan perbaikan pada ruang yang ada, memperbaiki keseluruhan desain ruang atau mengkonfirmasikan bahwa ruang yang baru dirancang atau didesain ulang mendukung perilaku yang dituju. Terdapat beberapa variasi metode pemetaan perilaku, antara lain: [1] Person Centered Mapping: Metode ini menekankan pada pergerakan manusia pada suatu periode waktu tertentu, serta metode ini hanya berhadapan dengan seseorang yang diamati (Makalew \& Waani, 2015). [2] Place Centered Mapping: Makalew \& Waani (2015) menjelaskan metode ini bertujuan untuk mengetahui bagaimana manusia atau sekelompok manusia memanfaatkan, menggunakan atau mengakomodasikan perilakunya dalam suatu situasi waktu dan tempat tertentu. Metode ini tidak memerlukan tracking/pelacakan pada setiap gerakan individu melalui sebuah ruang. Sebaliknya, area/ruang tersebut dengan cepat disurvei sekaligus dan semua perilaku dicatat di peta. Selanjutnya "snapshot" dapat diambil pada interval waktu tertentu untuk membantu mengidentifikasi pola yang konsisten. Sehingga peneliti dapat menentukan bagaimana berbagai area dalam ruang yang digunakan. (Ratodi, 2017). [3] Time Lapse Video: Ratodi (2017) menjelaskan bahwa variasi metode time lapse-video berguna untuk merekam pola kendaraan, pejalan kaki, maupun penggunaan ruang dalam periode yang lebih lama.

\section{Metode}

Penelitian ini merupakan penelitian yang berkaitan dengan perilaku manusia dan ruang. Penelitian ini menggunakan metode behavior mapping yaitu place centered mapping. Teknik pengumpulan data yang digunakan observasi place centered mapping, penyebaran kuesioner serta dokumentasi. Terdapat 2 variabel penelitian yaitu variabel arsitektur lingkungan dan perilaku yang terdiri dari setting perilaku, preferensi \& persepsi, dan kepadatan, serta variabel penataan internal yang terdiri dari fasilitas, sirkulasi dan tata ruang. Data hasil observasi place centered mapping dianalisis secara deskriptif didukung dengan hasil dari kuesioner. Berikut adalah skema metodologi penelitian:

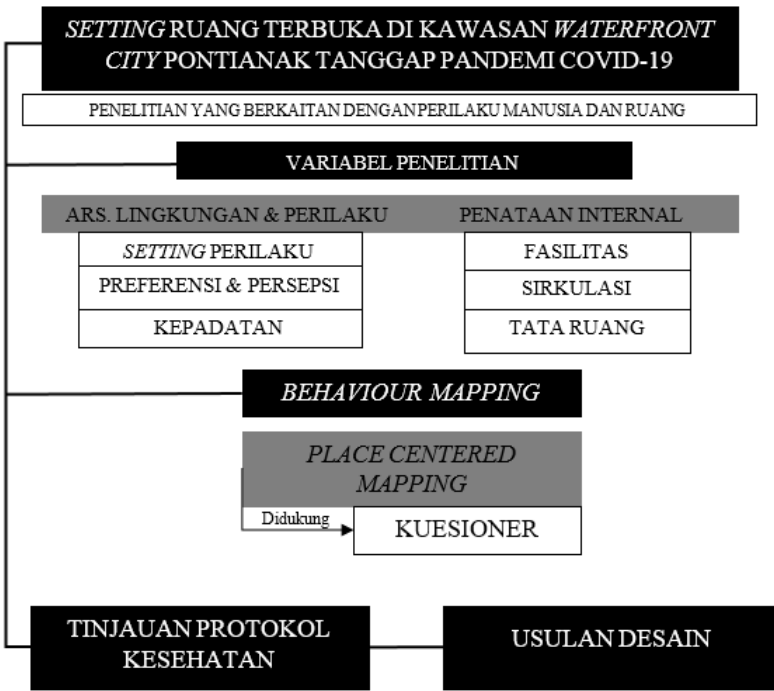

Gambar 1. Skema Metodologi Penelitian Sumber: Penulis, 2021 
- Area Pengamatan

Area pengamatan dibagi menjadi 3 (tiga) area berdasarkan letak pintu masuk utama serta kegiatan dominan saat observasi awal. Area A merupakan area yang dimulai dari pintu utama 1 yang berada di ujung Jalan Barito sampai pada batasan sebelum pintu utama 2. Area B merupakan area yang dimulai dari pintu utama 2 yang berada di ujung Gang Irian sampai pada batasan sebelum pintu masuk Gang Asean. Area C merupakan area yang dimulai dari pintu masuk Gang Asean atau area dimulainya kegiatan kafe Waterfront hingga ujung yang dibatasi oleh pagar.

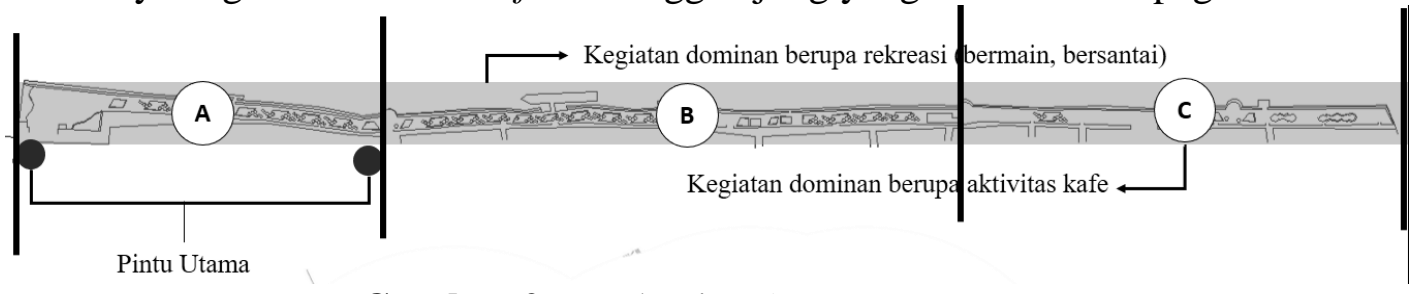

Gambar 2. Pembagian Area Pengamatan

Sumber: Penulis, 2021

- Waktu Pengamatan

Sesuai dengan penelitian yang mengangkat fenomena pandemi covid-19, maka waktu pengataman akan dipilih berdasarkan tingkat ramai kunjungan. Berdasarkan data yang diperoleh dari Google Maps, hari sabtu dan minggu menjadi hari dengan tingkatkan kunjung paling tinggi. Melihat adanya perbedaan antara aktivitas pagi-siang dan sore-malam, maka penelitian akan dilakukan pada 2 waktu yang berbeda yaitu pagi-siang dan sore-malam.

- Simbol Aktivitas Place Centered Mapping

\begin{tabular}{|l|c|}
\hline \multicolumn{1}{|c|}{ AKTIVITAS } & \multicolumn{2}{c|}{ SIMBOL SKETSA } \\
\hline Jogging & Aktivitas Olahraga \\
\hline Senam & \\
\hline Peregangan & \\
\hline \multicolumn{2}{|c|}{ Aktivitas Hobi } \\
\hline Memancing \\
\hline Berfoto \\
\hline \multicolumn{2}{|c|}{ Aktivitas Rekreasi } \\
\hline Bersepeda \\
\hline Bermain mobil-mobilan (anak-anak) \\
\hline Makan/Minum \\
\hline Menggambar \\
\hline Aktivitas Komersil \\
\hline Berjualan \\
\hline Berbelanja/Membeli sesuatu \\
\hline Aktivitas Servis \\
\hline Bersih-bersih \\
\hline Berjal an \\
\hline Duduk \\
\hline Berdiri \\
\hline Gambtivitas Lainnya \\
\hline
\end{tabular}

Gambar 3. Simbol Sketsa Place Centered Mapping

Sumber: Penulis, 2021 


\section{Hasil dan Pembahasan}

Hasil dan pembahasan dibagi menjadi beberapa poin, antara lain:

\section{Analisis Data Place Centered Mapping}

Place centered mapping dilakukan pada 2 waktu yang berbeda, yaitu pagi-siang dan soremalam. Data place centered mapping akan di sajikan dalam 3 mapping area dengan simbol aktivitas yang telah ditentukan.

Tabel 1. Hasil Place Centered Mapping

\section{AREA A}

\section{PAGI-}

SIANG

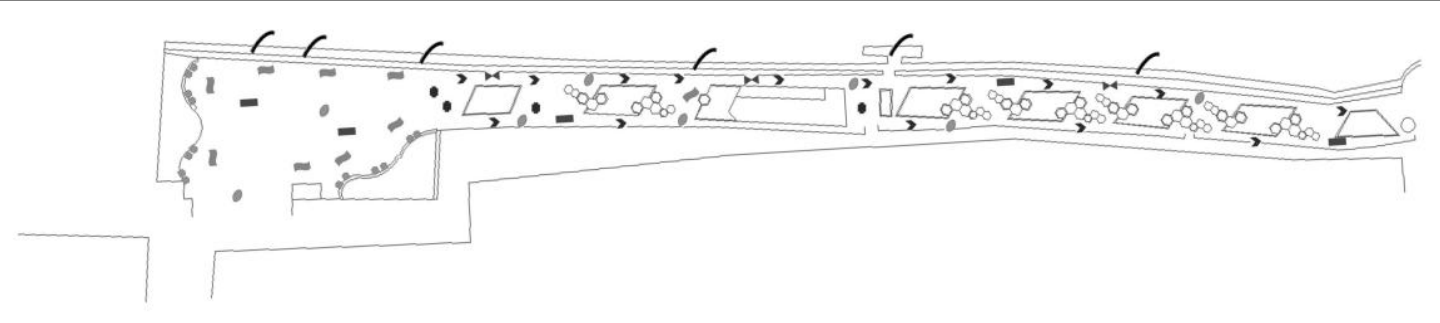

SORE-

MALAM

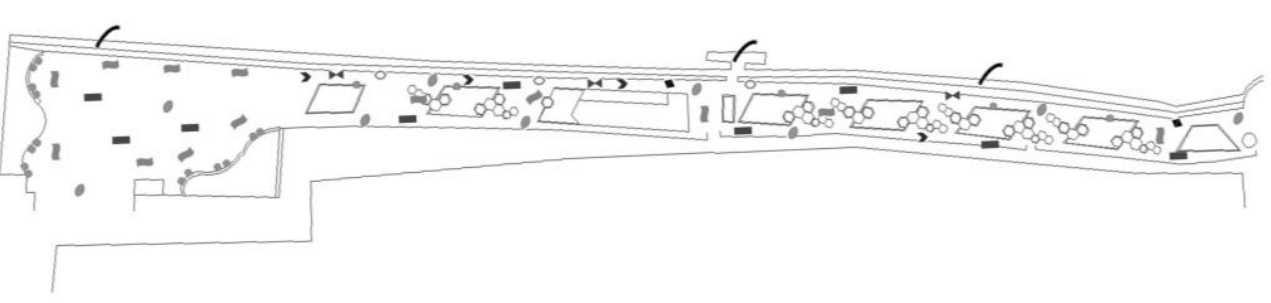

AREA B

PAGI-

SIANG

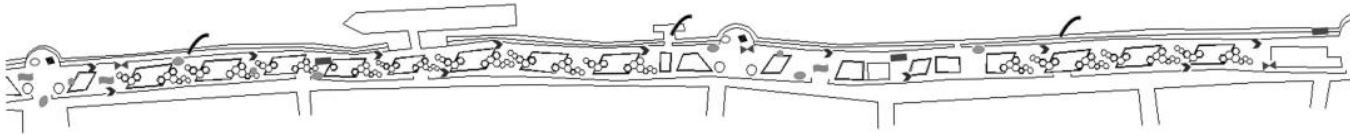

SORE-

MALAM

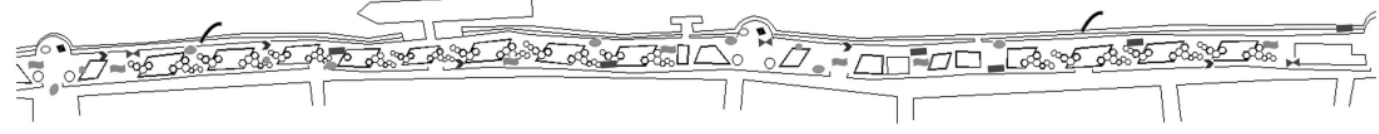

\section{AREA C}

PAGI-

SIANG

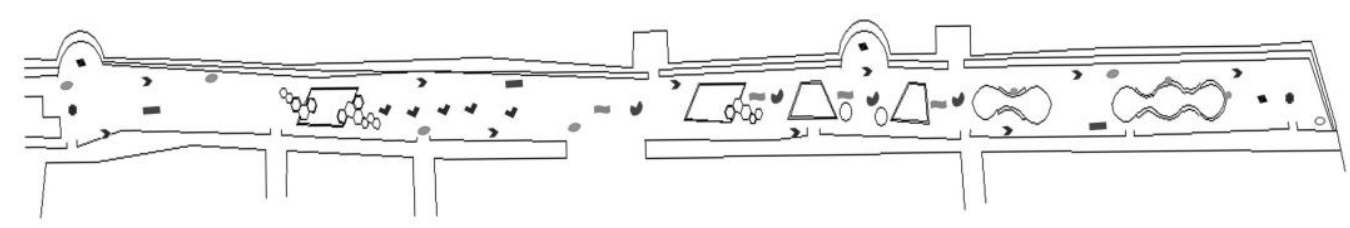




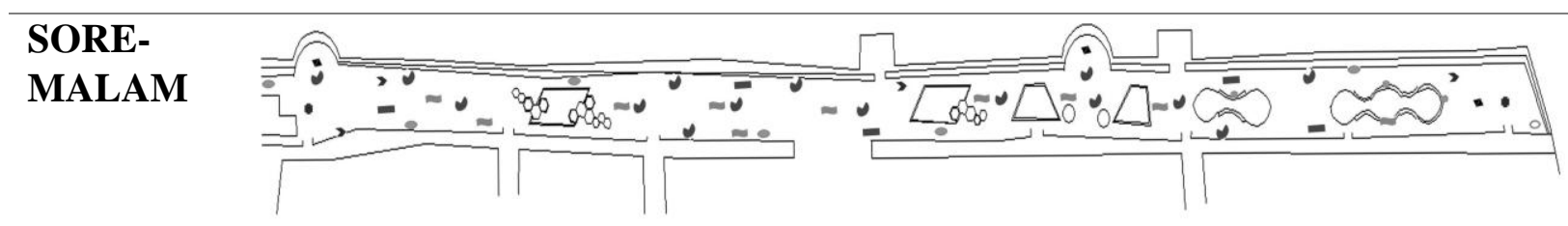

Sumber: Penulis, 2021

Hasil place centered mapping pada Area A menunjukkan terdapat persamaan dan perbedaan aktivitas di pagi-siang hari dan sore-malam hari. Persamaan aktivitas terjadi pada dekat dari pintu masuk Jalan Barito, yang digunakan sebagai tempat untuk kegiatan komersial seperti berjualan, penyewaan mainan dan sebagainya. Perbedaan paling signifikan yang terlihat di Area A adalah aktivitas yang dilakukan pengunjung. Aktivitas dominan pada waktu pagi-siang hari adalah olahraga, sedangkan pada sore-malam hari adalah rekreasi. Hasil place centered mapping pada Area B menunjukkan perbedaan signifikan yang terlihat adalah aktivitas yang dilakukan pengunjung seperti pada Area A. Selain itu, pada pagi-siang hari Area B relatif lebih sepi dan hanya dijadikan sebagai jalur penghubung antara Area A dan Area C. Hasil place centered mapping pada Area C menunjukkan terdapat persamaan dan perbedaan aktivitas yang dilakukan pengunjung di pagi-siang hari dan sore-malam hari. Persamaan yang terjadi di Area C pada waktu pagi-siang hari dan soremalam hari adalah area ini di dominasi oleh kegiatan rekreasi. Beberapa perilaku pengunjung dalam memanfaatkan ruang dan fasilitas yang diperoleh dari hasil pengumpulan data place centered mapping di Waterfront City Pontianak saat pandemi covid-19, antara lain:

Tabel 2. Perilaku Pengguna

\section{PERILAKU} FOTO

Pengunjung telah menerapkan salah satu dari protokol kesehatan covid-19, yaitu menggunakan masker.

Pengunjung bersantai di dekat pagar pembatasan dan bersandar menyentuh pagar tersebut.

Pengunjung jarang memanfaatkan fasilitas cuci tangan yang telah tersedia.

Fasilitas tempat duduk dan pot tanaman belum menerapkan desain tanggap pandemi covid-19. Selain itu, tempat duduk yang memiliki ukuran besar dimanfaatkan sebagai lapak untuk berjualan.

Tidak terpenuhinya minimal batasan jaga jarak saat pandemi covid-19. Hal ini terlihat dari terbentuknya kerumunan di ruang-ruang yang ada, terutama jalur sirkulasi.

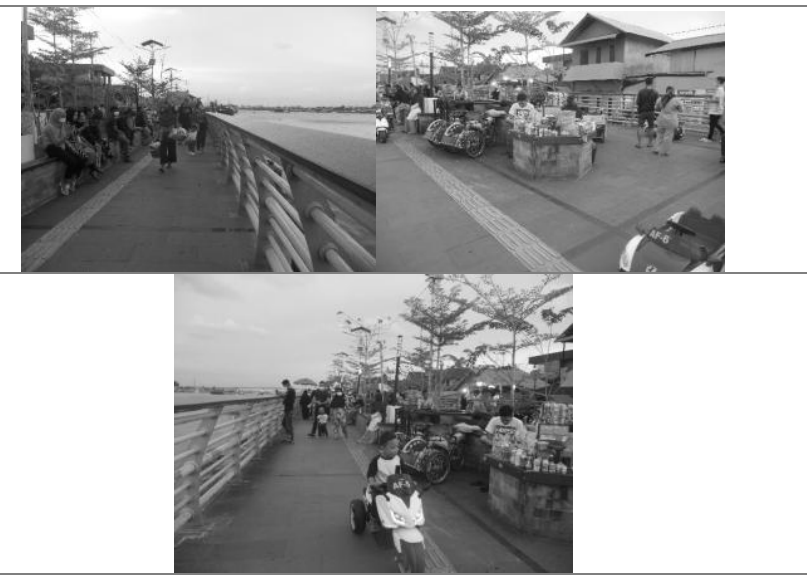


Ruang dengan luasan yang lebih besar dimanfaatkan untuk kegiatan komersil dan rekreasi, seperti pada Area A yang menyebabkan crowded.

Ruang di antara tempat duduk dan pot tanaman dimanfaatkan sebagai lapak berjualan, menyebabkan pengunjung yang ingin memutar arah jalur sirkulasi akan terhambat dan akhirnya terjadi kemacetan.

Ruang pada Area C di manfaatkan sebagai area komersil dan rekreasi terutama aktivitas kafe. Saat ini tidak terlihat adanya batasan jarak maupun jumlah antara bangku-bangku kafe, sehingga terjadi kepadatan.

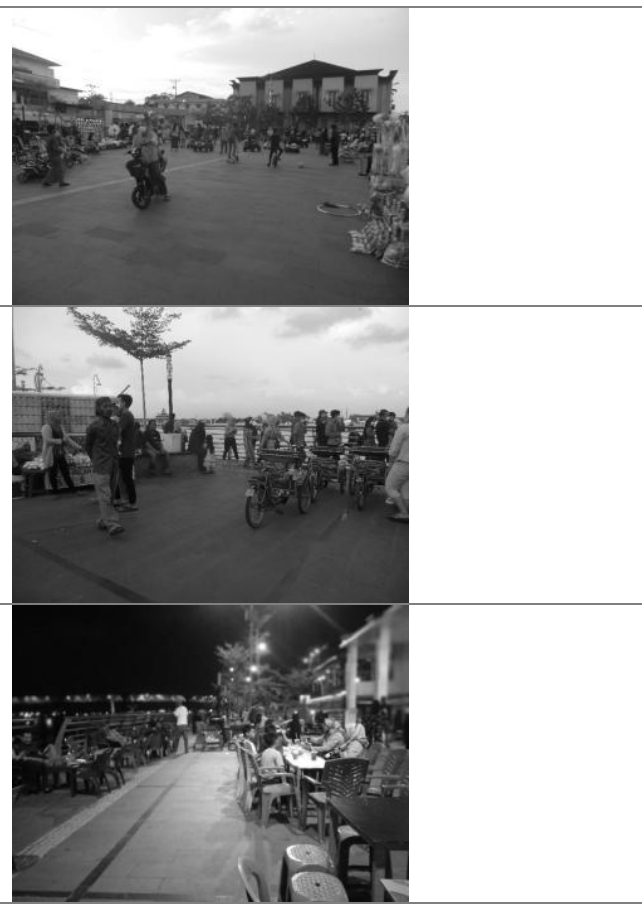

Sumber: Penulis, 2021

\section{Analisis Kuesioner}

Kuesioner disebarkan secara online melalui google form. Data yang diperoleh berjumlah 75 sampel. Narasumber yang mengisi kuesioner merupakan pengunjung yang pernah berkunjung ke Waterfront City Pontianak di saat pandemi covid-19. Analisis data kuesioner dibagi menjadi 2 jenis data yaitu data umum serta data preferensi dan persepsi.

1. Data Umum

Data umum meliputi data-data umum narasumber yang mengisi kuesioner.

Tabel 3. Hasil Kuesioner (Data Umum)

\begin{tabular}{|c|c|c|c|c|c|c|}
\hline Kategori & & & Pilihan & & & Ket \\
\hline \multirow{2}{*}{ Jenis Kelamin } & Pria & Wanita & & & & \multirow{2}{*}{$\%$} \\
\hline & 39 & 61 & & & & \\
\hline \multirow[t]{2}{*}{ Usia } & $\begin{array}{l}\text { Kurang dari } \\
20 \text { tahun }\end{array}$ & $\begin{array}{l}\text { Antara 20- } \\
30 \text { tahun }\end{array}$ & $\begin{array}{l}\text { Antara 30- } \\
40 \text { tahun }\end{array}$ & $\begin{array}{c}\text { Antara } 40-50 \\
\text { tahun }\end{array}$ & $\begin{array}{l}\text { Lebih dari } \\
50 \text { tahun }\end{array}$ & \multirow[t]{2}{*}{$\%$} \\
\hline & 19 & 80 & 1 & 0 & 0 & \\
\hline \multirow[t]{2}{*}{$\begin{array}{l}\text { Intensitas } \\
\text { kunjungan }\end{array}$} & $\begin{array}{l}\text { Sangat } \\
\text { jarang }\end{array}$ & Jarang & $\begin{array}{l}\text { Cukup } \\
\text { sering }\end{array}$ & Sering & $\begin{array}{l}\text { Sangat } \\
\text { sering }\end{array}$ & \multirow[t]{2}{*}{$\%$} \\
\hline & 40 & 30 & 23 & 7 & 0 & \\
\hline \multirow[t]{2}{*}{ Jenis kelompok } & Sendiri & Kel. kecil & Kel. sedang & Kel. besar & $\begin{array}{l}\text { Kel. sangat } \\
\text { besar }\end{array}$ & \multirow[t]{2}{*}{$\%$} \\
\hline & 5 & 51 & 35 & 9 & 0 & \\
\hline \multirow[t]{2}{*}{$\begin{array}{c}\text { Waktu } \\
\text { kunjungan }\end{array}$} & Pagi hari & Sore hari & $\begin{array}{l}\text { Pagi dan } \\
\text { Sore hari }\end{array}$ & & & \multirow[t]{2}{*}{$\%$} \\
\hline & 4 & 88 & 8 & & & \\
\hline \multirow{2}{*}{$\begin{array}{l}\text { Aktivitas yang } \\
\text { dilakukan }\end{array}$} & Olahraga & Rekreasi & Komersil & Hobi & Lainnya & \multirow{2}{*}{ Jlh } \\
\hline & 6 & 69 & 1 & 7 & - & \\
\hline
\end{tabular}

Sumber: Penulis, 2021 
2. Data Preferensi dan Persepsi

Data preferensi dan persepsi meliputi data-data yang lebih khusus dan dibutuhkan dalam penelitian.

Tabel 4. Hasil Kuesioner (Data Preferensi dan Persepsi)

\begin{tabular}{|c|c|c|c|c|c|}
\hline Kategori & & Pilihan & & & Ket \\
\hline \multirow{2}{*}{$\begin{array}{c}\text { Pintu masuk yang } \\
\text { dilewati }\end{array}$} & $\begin{array}{c}\text { Pintu masuk Jalan } \\
\text { Barito }\end{array}$ & $\begin{array}{l}\text { Pintu masuk } \\
\text { Gang Irian }\end{array}$ & $\begin{array}{l}\text { Pintu masuk } \\
\text { sekunder }\end{array}$ & & \multirow[t]{2}{*}{$\mathrm{Jlh}$} \\
\hline & 40 & 30 & 10 & & \\
\hline \multirow[t]{2}{*}{$\begin{array}{l}\text { Fasilitas pandemi } \\
\text { covid-19 yang tersedia }\end{array}$} & $\begin{array}{l}\text { Fasilitas cuci } \\
\text { tangan }\end{array}$ & $\begin{array}{c}\text { Peringatan } \\
\text { untuk menjaga } \\
\text { jarak }\end{array}$ & $\begin{array}{l}\text { Media } \\
\text { informasi } \\
\text { covid-19 }\end{array}$ & $\begin{array}{c}\text { Pos } \\
\text { kesehatan } \\
\text { covid-19 }\end{array}$ & \multirow[t]{2}{*}{$\mathrm{Jlh}$} \\
\hline & 58 & 33 & 42 & 7 & \\
\hline \multirow{2}{*}{$\begin{array}{l}\text { Ketersediaan fasilitas } \\
\text { cuci tangan }\end{array}$} & Sudah & Belum & & & \multirow{2}{*}{$\%$} \\
\hline & 88 & 12 & & & \\
\hline \multirow{2}{*}{$\begin{array}{c}\text { Ketersediaan } \\
\text { kelengkapan fasilitas } \\
\text { cuci tangan }\end{array}$} & Baik & Cukup & Tidak baik & & \multirow{2}{*}{$\%$} \\
\hline & 3 & 69 & 28 & & \\
\hline \multirow{2}{*}{$\begin{array}{c}\text { Usulan desain fasilitas } \\
\text { cuci tangan }\end{array}$} & Desain 1 & Desain 2 & & & \multirow{2}{*}{$\%$} \\
\hline & 4 & 96 & & & \\
\hline \multirow{2}{*}{$\begin{array}{l}\text { Usulan perletakan } \\
\text { fasilitas cuci tangan }\end{array}$} & Perletakan 1 & Perletakan 2 & & & \multirow{2}{*}{$\%$} \\
\hline & 56 & 44 & & & \\
\hline \multirow{2}{*}{$\begin{array}{l}\text { Ketersediaan } \\
\text { peringatan untuk } \\
\text { menjaga jarak }\end{array}$} & Sudah & Belum & & & \multirow{2}{*}{$\%$} \\
\hline & 53 & 47 & & & \\
\hline \multirow{2}{*}{$\begin{array}{l}\text { Kejelasan peringatan } \\
\text { untuk menjaga jarak }\end{array}$} & Jelas & Cukup & Tidak jelas & & \multirow{2}{*}{$\%$} \\
\hline & 3 & 49 & 48 & & \\
\hline \multirow{2}{*}{$\begin{array}{c}\text { Usulan desain tempat } \\
\text { duduk dan pot } \\
\text { tanaman }\end{array}$} & Desain 1 & Desain 2 & Desain 3 & & \multirow[t]{2}{*}{$\%$} \\
\hline & 27 & 48 & 25 & & \\
\hline \multirow{2}{*}{$\begin{array}{l}\text { Ketersediaan media } \\
\text { informasi covid-19 }\end{array}$} & Sudah & Belum & & & \multirow{2}{*}{$\%$} \\
\hline & 69 & 31 & & & \\
\hline \multirow{2}{*}{$\begin{array}{l}\text { Kejelasan media } \\
\text { informasi covid-19 }\end{array}$} & Jelas & Cukup & Tidak jelas & & \multirow[t]{2}{*}{$\%$} \\
\hline & 7 & 60 & 33 & & \\
\hline \multirow{2}{*}{$\begin{array}{l}\text { Usulan desain media } \\
\text { informasi covid-19 }\end{array}$} & Desain 1 & Desain 2 & & & \multirow[t]{2}{*}{$\%$} \\
\hline & 4 & 96 & & & \\
\hline \multirow{2}{*}{$\begin{array}{l}\text { Usulan perletakan } \\
\text { media informasi } \\
\text { covid-19 }\end{array}$} & Perletakan 1 & Perletakan 2 & & & \multirow{2}{*}{$\%$} \\
\hline & 64 & 36 & & & \\
\hline \multirow{2}{*}{$\begin{array}{l}\text { Ketersediaan pos } \\
\text { kesehatan covid-19 }\end{array}$} & Sudah & Belum & & & \multirow[t]{2}{*}{$\%$} \\
\hline & 20 & 80 & & & \\
\hline
\end{tabular}




\begin{tabular}{ccccc}
\hline Kondisi letak pos & Baik & Cukup & Tidak baik & $\%$ \\
\cline { 2 - 4 } kesehatan covid-19 & 3 & 21 & 76 & \\
\hline $\begin{array}{c}\text { Usulan perletakan pos } \\
\text { kesehatan covid-19 }\end{array}$ & Perletakan 1 & Perletakan 2 & & $\%$ \\
\hline \multirow{2}{*}{ Ketersedian pengawas } & 45 & 55 & & $\%$ \\
\hline
\end{tabular}

Sumber: Penulis, 2021

Hasil kuesioner data preferensi dan persepsi menunjukkan bahwa pintu masuk Jalan Barito menjadi pilihan utama untuk masuk ke Waterfront City Pontianak. Hal ini sejalan dengan hasil place centered mapping yang menunjukkan ruang didekat pintu masuk Jalan Barito ramai dikunjungi beragam aktivitas. Fasilitas protokol kesehatan yang tersedia di Waterfront City Pontianak berdasarkan hasil kuesioner adalah fasilitas cuci tangan (jawaban dari 58 narasumber), media informasi covid-19 (jawaban dari 42 narasumber), peringatan untuk menjaga jarak (jawaban dari 33 narasumber), dan pos kesehatan covid-19 (jawaban dari 33 narasumber). Hal ini tidak sejalan dengan hasil place centered mapping karena saat observasi pengumpulan data hanya ditemukan fasilitas cuci tangan.

Hasil kuesioner mengenai fasilitas cuci tangan di Waterfront City Pontianak menunjukkan $88 \%$ narasumber yang berpendapat bahwa sudah tersedianya fasilitas cuci tangan. Mayoritas narasumber dengan presentase $69 \%$ berpendapat bahwa ketersediaan kelengkapan fasilitas cuci tangan di kategori cukup (air mengalir dengan baik, dan selalu tersedia sabun). Selain itu, narasumber merasa perlu adanya perubahan desain fasilitas cuci tangan. Mayoritas narasumber memilih desain 2 dengan presentase 96\%. Desain 2 merupakan desain fasilitas cuci tangan dengan wastafel yang menggunakan pijakan kaki untuk membuka keran sehingga dapat mengurangi kontak fisik (lihat Gambar 4.15). Selain usulan desain, 56\% narasumber berpendapat bahwa perletakkan fasilitas cuci tangan perlu diletakkan di usulan perletakan 1 yaitu di antara tempat duduk dan pot tanaman (di tengah).

Hasil kuesioner mengenai peringatan untuk menjaga jarak batasan jarak duduk, berdiri, dsb) di Waterfront City Pontianak menunjukkan 53\% narasumber yang berpendapat bahwa sudah tersedianya peringatan untuk menjaga jarak. Mayoritas narasumber dengan presentase $49 \%$ berpendapat bahwa kejelasan peringatan untuk menjaga jarak dikategori cukup jelas (terdapat batasan peringatan seperti tanda silang, dsb) dan $48 \%$ narasumber berpendapat dikategori tidak jelas (tidak terdapat peringatan untuk menjaga jarak). Selain itu, narasumber merasa perlu adanya perubahan desain fasilitas tempat duduk dan pot tanaman karena desain saat ini belum menerapkan penjagaan jarak. Mayoritas narasumber memilih desain 2 dengan presentase $48 \%$. Desain 2 merupakan tempat duduk diantara pot tanaman dengan jarak diantara bangku (lihat Gambar 4.16).

Hasil kuesioner mengenai media informasi covid-19 (banner, plank, dsb) di Waterfront City Pontianak menunjukkan 69\% narasumber yang berpendapat bahwa sudah tersedianya media informasi covid-19. Mayoritas narasumber dengan presentase $60 \%$ berpendapat bahwa kejelasan media informasi covid-19 di kategori cukup (terdapat media informasi covid-19, akan tetapi desain dan penataan yang kurang baik). Selain itu, narasumber merasa perlu adanya perubahan desain media informasi covid-19. Mayoritas narasumber memilih desain 2 dengan presentase $96 \%$. Desain 2 merupakan desain media informasi covid-19 berupa papan informasi digital (lihat Gambar 4.17). Selain usulan desain, 64\% narasumber berpendapat bahwa perletakkan media informasi covid-19 perlu diletakkan di usulan perletakan 1 yaitu di antara tempat duduk dan pot tanaman (di tengah).

Hasil kuesioner mengenai pos kesehatan covid-19 di Waterfront City Pontianak menunjukkan $80 \%$ narasumber yang berpendapat bahwa belum tersedianya pos kesehatan covid-19. Mayoritas narasumber dengan presentase $76 \%$ berpendapat bahwa kondisi pos kesehatan covid-19 di kategori 
tidak baik (tidak terdapat pos kesehatan covid-19). Selain itu, 55\% narasumber berpendapat bahwa pos kesehatan covid-19 perlu diletakkan di usulan perletakan 2 yaitu di tengah Waterfront City Pontianak. Hasil kuesioner mengenai pengawasan terkait protokol kesehatan covid-19 di Waterfront City Pontianak menunjukkan $83 \%$ narasumber berpendapat bahwa belum adanya pengawas yang tersedia.

\section{Tinjauan Protokol Kesehatan}

Protokol kesehatan covid-19 telah diatur dalam Kemenkes Republik Indonesia Tentang Protokol Kesehatan Bagi Masyarakat di Tempat dan Fasilitas Umum Dalam Rangka Pencegahan dan Pengendalian Corona Virus Disease 2019 (Covid-19). Adapun poin-poin yang menjadi tinjauan antara lain:

1. Penerapan Jaga Jarak

- Pembatasan jumlah pengunjung

Saat ini belum ada pembatasan jumlah pengunjung sehingga terjadi kepadatan di waktu-waktu tertentu.

- Penanda di lantai minimal 1 meter (seperti di pintu masuk, kasir, dan lain-lain)

Saat ini belum adanya penanda di lantai sebagai batasan jarak.

- Pengaturan alur pengunjung

Saat ini belum adanya pengaturan terkait alur pengunjung.

2. Penyediaan fasilitas cuci tangan

Saat ini sudah tersedia fasilitas cuci tangan dibeberapa titik didekat pintu masuk. Fasilitas cuci tangan yang ada masih berupa desain temporer yaitu tandon air dan wastefel sederhana.

3. Penyediaan pos kesehatan

Saat ini belum tersedia pos kesehatan.

4. Media informasi

Media informasi terkait pandemi covid-19 seperti wajib menggunakan masker, jaga jarak minimal 1 meter, cuci tangan di seluruh lokasi. Saat ini belum tersedianya media informasi terkait pandemi covid-19.

Berkaitan dengan tinjauan protokol kesehatan yang telah dijabarkan, beberapa hal yang perlu diperbaiki di Waterfront City Pontianak agar dapat dikatakan tanggap pandemi covid-19, antara lain:

1. Membuat peraturan terkait pembatasan pengunjung. Hal ini dapat berupa penyediaan tiket masuk sehingga dapat memantau jumlah pengunjung yang ada dalam waktu yang bersamaan.

2. Menambahkan penandaan untuk menjaga jarak di lantai Waterfront City Pontianak.

3. Membuat peraturan alur pengunjung sehingga tidak terjadi crossing antar pengunjung dari arah yang berbeda, serta untuk menghindari kontak fisik.

4. Menyediakan fasilitas cuci tangan, pos kesehatan, dan media informasi untuk mendukung protokol kesehatan covid-19.

5. Menyediakan pengawas untuk mengawasi protokol kesehatan covid-19 baik itu disetiap pintu masuk maupun pengawas yang berkeliling untuk memantau pengunjung. Selain itu, dapat disediakan voice record atau microphone yang dapat memperingati pengunjung dalam jangka waktu tertentu dari jarak jauh. 


\section{Usulan Desain}

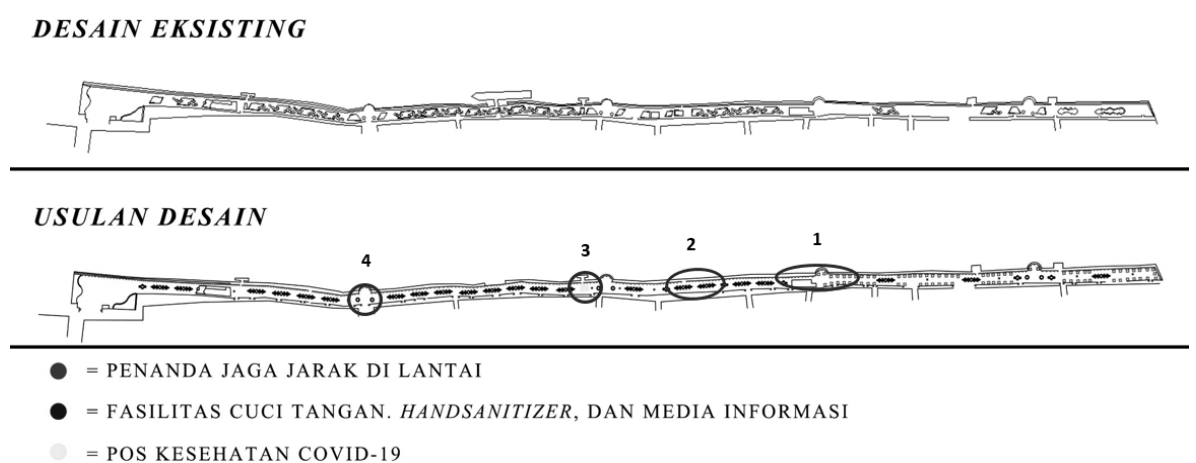

Gambar 4. Usulan Desain

Sumber: Penulis, 2021

Usulan desain akan berfokus pada fasilitas terkait protokol kesehatan covid-19. Usulan desain dibagi menjadi beberapa poin, yaitu:

1. Menambahkan penanda di lantai Waterfront City Pontianak untuk menjaga jarak.

Terdapat 2 jenis penanda lantai, penanda lantai 1 merupakan penandai di lantai untuk pengunjung yang ingin berhenti di tepi pagar, penanda lantai 2 merupakan penanda di lantai untuk menjaga jarak susunan kursi dan meja pada kegiatan kafe di area $\mathrm{C}$.

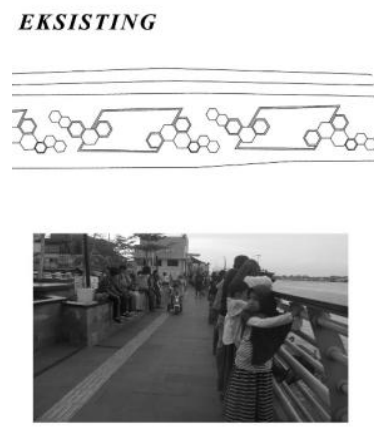

(a) Penanda Lantai 1

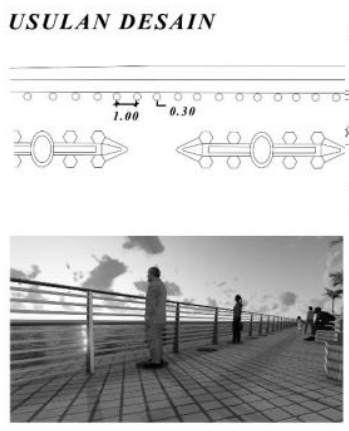

Gambar 5. Penanda Jaga Jarak di Lantai

2. Perubahan desain tempat duduk dan pot tanaman.

Tempat duduk didesain berjarak, selain itu ukuran tempat duduk lebih kecil dari pada yang ada saat ini. Hal ini untuk menghindari pemanfaatkan tempat duduk sebagai aktivitas lain, ataupun diduduki lebih dari 1 orang.

EKSISTING

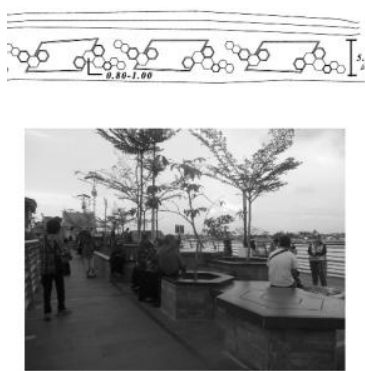

Gambar 6. Fasilitas Tempat Duduk dan Pot Tanaman
USULAN DESAIN
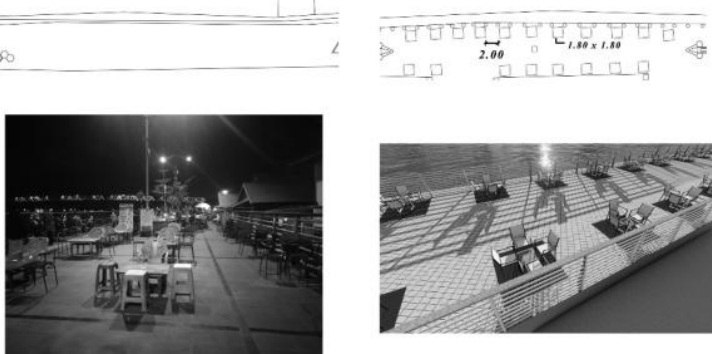

(b) Penanda Lantai 2

Sumber: Penulis, 2021

Sumber: Penulis, 2021 
3. Penyediaan fasilitas pos kesehatan covid-19

Pos kesehatan merupakan tenda yang menyediakan kebutuhan medis terkait covid-19, serta tempat darurat jika terjadi hal-hal yang tidak diinginkan.

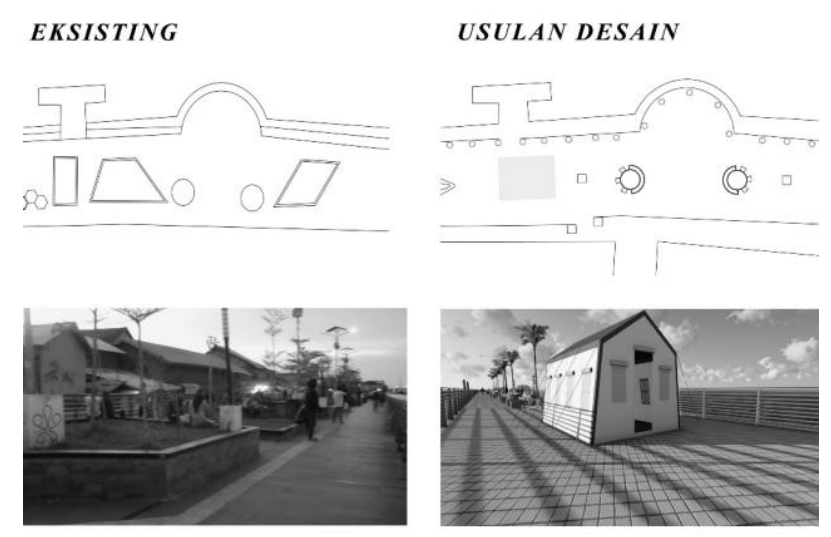

Gambar 7. Pos Kesehatan Covid-19

Sumber: Penulis, 2021

4. Penyediaan fasilitas cuci tangan, handsanitizer, dan media informasi covid-19.

Fasilitas cuci tangan didesain dengan inovasi cara membuka keran dengan pijakan kaki, sehingga dapat mengurangi kontak fisik. Handsanitizer didesain dengan sensor otomatis. Media informasi didesain dengan digital board. Tempat cuci tangan dan media informasi diletakkan di dekat pintu masuk. Selain itu, diantara bangku-bangku dan pot tanaman diletakkan handsanitizer dan media informasi.

$$
\text { EKSISTING USULAN DESAIN }
$$

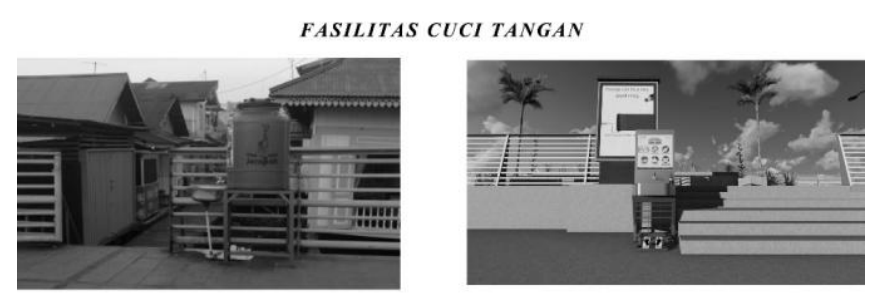

HANDSANITIZER \& MEDIA INFORMASI COVID-19
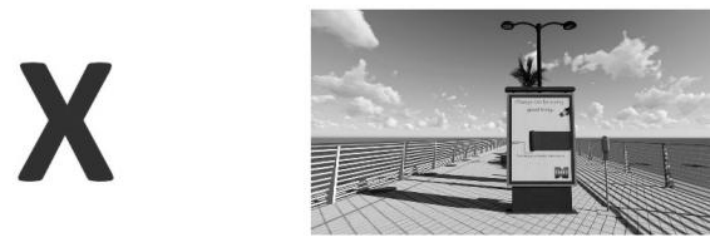

Gambar 8. Fasilitas Cuci Tangan, Handsanitizer, dan Media Informasi

Sumber: Penulis, 2021

\section{Kesimpulan}

Setting ruang terbuka Waterfront City Pontianak menunjukkan belum tanggap terhadap pandemi covid-19, sehingga perlu adanya perubahan dan perbaikan pada beberapa hal. Hal-hal yang perlu diperbaiki pada setting ruang terbuka Waterfront City Pontianak difokuskan pada desain dan perletakan fasilitas terkait pandemi covid-19. Solusi atau usulan desain yang dihasilkan terlihat pada penambahan penanda jaga jarak di lantai, perubahan desain tempat duduk dan pot tanaman, 
penyediaan fasilitas pos kesehatan covid-19, penyediaan fasilitas cuci tangan, handsanitizer, dan media informasi covid-19.

\section{Ucapan Terima Kasih}

Alhamdulillah, segala puji bagi Allah Subhanahu Wa Ta'ala, atas berkat dan rahmatnya saya dapat menyelesaikan penulisan jurnal ini. Terima kasih kepada kedua orang tua yang selalu memberikan dukungan, kepada para dosen pembimbing yaitu bapak M. Nurhamsyah, S.T., M.Sc. selaku pembimbing utama dan ibu Bontor Jumaylinda BR Gultom, S.T., M.T. selaku pembimbing pendamping, serta kepada para pihak-pihak lain yang tidak dapat disebutkan satu persatu.

\section{Daftar Acuan}

Avenzoar, A., Sunarti, E. T., \& Soemardiono, B. (2013). Penataan Taman Kota Yang Efektif Sebagai Ruang Terbuka Hijau dan Ruang Sosial Bagi Masyarakat. Studi Kasus: Taman Kota di Surabaya. May 2013, 1-10

Cosco, N. G., Moore, R. C., \& Islam, M. Z. (2010). Behavior mapping: A method for linking preschool physical activity and outdoor design. Medicine and Science in Sports and Exercise, 42(3), 513-519. https://doi.org/10.1249/MSS.0b013e3181cea27a

Darmawan, E. (2007). Peranan Ruang Publik dalam Perancangan Kota (Urban Design)

Fadli, A. (2020, April 21). Mengenal COVID-19 dan Cegah Penyebarannya dengan "Peduli Lindungi" Aplikasi Berbasi Android. Artikel Pengabdian Kepada Masyarakat Jurusan Teknik Elektro, di Desa Blater Kecamatan Kalimanah Kabupaten Purbalingga, pp. 1-6

Haryadi, \& Setiawan, B. (2014). Aristektur, Lingkungan dan Perilaku. Yogyakarta: Gajah Mada University Press

Hua, J., \& Shaw, R. (2020). Corona Virus (COVID-19) "Infodemic" and Emerging Issues through a Data Lens: The Case of China. International Journal of Environmental Research and Public Health, 17(7), 1-12. https://doi.org/10.1016/j.ijid.2020.04.033\%0Ahttp://www.ncbi.nlm.nih.gov/pubmed/32460566

Hunter, M. C. R., Gillespie, B. W., \& Chen, S. Y. P. (2019). Urban nature experiences reduce stress in the context of daily life based on salivary biomarkers. Frontiers in Psychology, 10(APR), 1-16. https://doi.org/10.3389/fpsyg.2019.00722

Kementerian Dalam Negeri Republik Indonesia. (2007). Peraturan Menteri Dalam Negeri Republik Indonesia No.1 Tahun 2007 Tentang Penataan Ruang Terbuka Hijau Kawasan Perkotaan. Jakarta: Kementerian Dalam Negeri Republik Indonesia Kementerian Dalam Negeri Republik Indonesia

Kementerian Kesehatan Republik Indonesia. (2020). Keputusan Menteri Kesehatan No. HK.01.07/MENKES/382/2020 Tentang Protokol Kesehatan Bagi Masyarakat di Tempat dan Fasilitas Umum dalam Rangka Pencegahan dan Pengendalian Corona Virus Disease 2019 (COVID-19). Jakarta: Kementerian Kesehatan Republik Indonesia

Kraemer, Zhang, J., Feng, B., Wu, Y., Xu, P., Ke, R., \& Dong, N. (2020). The effect of human mobility and control measures on traffic safety during COVID-19 pandemic. Science 368, $493-497$. https://doi.org/10.1371/journal.pone.0243263

Larasati, R. (2016). Pengaruh Stress Pada Kesehatan Jaringan Periodontal. Skala Husada, 13(1 April 2016), 81-89

Makalew, V. L., \& Waani, J. O. (2015). Pengamatan Arsitektur dan Perilaku Studi Kasus Paud GMIM Karunia Tumpaan-Kakas. Temu Ilmiah Iplbi, 1, 159-166

Nochian, A., Mohd Tahir, O., Maulan, S., \& Rakhshandehroo, M. (2015). A comprehensive public open space categorization using classification system for sustainable development of public open spaces. ALAM CIPTA, International Journal on Sustainable Tropical Design Research \& Practice, 8(spec.1), 29-40

Nur'aini, R. D., Rahmah, G. L. N., \& Septiawan, T. (2018). Pengaruh Desain Lansekap Terhadap Perilaku Pengunjung Pada Taman Kota Liwan Lake Park Guangzhou, China. Seminar Nasional Sains Dan Teknologi 2018, 1-9

Ratodi, M. (2017). Behavior Mapping - Pemetaan Perilaku dalam Penelitian \& Perancangan Arsitektur. Lecture material presented at the Perilaku Dalam Arsitektur, Surabaya

Samsudi. (2010). Ruang Terbuka Hijau Kebutuhan Tata Ruang Perkotaan Kota Surakarta. Journal of Rural and Development, Vol. 1(No. 1), Hal. 11-19

Sanoff, H., \& Coates, G. (1971). Behavioral mapping an ecological analysis of activities in a residential setting. International Journal of Environmental Studies, 2, 227-235. https://doi.org/10.1080/00207237108709471

Santoso, R. B. (2012). Pola Pemanfaatan Ruang Terbuka Hijau Pada Kawasan Perkampungan Plemburan Tegal,Ngaglik Sleman. Inersia, 8(1), 1-14. https://doi.org/10.21831/inersia.v8i1.3694

Shani, F. M., \& Kurniawan, A. (2015). Kajian Ketersediaan dan Kebutuhan Ruang Terbuka Hijau Kawasan Perkotaan di Kota Sukabumi. Bumi Indonesia, 4(3), 1-8

Sunaryo, R. G. (2010). Perubahan Setting Ruang dan Pola Aktivitas Publik di Ruang Terbuka Kampus UGM. Serap 1, $175-182$

Susilo, A., Rumende, C. M., Pitoyo, C. W., Santoso, W. D., Yulianti, M., Herikurniawan, H., Sinto, R., Singh, G., 
Nainggolan, L., Nelwan, E. J., Chen, L. K., Widhani, A., Wijaya, E., Wicaksana, B., Maksum, M., Annisa, F., Jasirwan, C. O. M., \& Yunihastuti, E. (2020). Coronavirus Disease 2019: Tinjauan Literatur Terkini. Jurnal Penyakit Dalam Indonesia, 7(1), 45. https://doi.org/10.7454/jpdi.v7i1.415

Telaumbanua, D. (2020). Urgensi Pembentukan Aturan Terkait Pencegahan Covid-19 di Indonesia. QALAMUNA: Jurnal Pendidikan, Sosial, Dan Agama, 12(01), 59-70. https://doi.org/10.37680/qalamuna.v12i01.290

Yustiara, D., \& Nirwansyah, R. (2018). Pendekatan Behavior Setting pada Penataan Lingkungan Kampung Akuarium dalam Desain Rumah Susun. Jurnal Sains Dan Seni ITS, 7(2), 76-79 